\begin{tabular}{|c|c|c|c|c|c|}
\hline \multirow{3}{*}{$\begin{array}{ll}\text { 2. ECN Category (mark one) } \\
\text { Supplemental } \\
\text { Direct Revision } \\
\text { Change ECN } \\
\text { Temporary } \\
\text { Standby } \\
\text { Supersedure }\end{array}$} & \multicolumn{2}{|c|}{$\begin{array}{l}\text { 3. Originator's Name, Organization, MSIN, and Telephone No. } \\
\text { Brian M Parker, SNEP, R3-86, 373-7800 }\end{array}$} & \multicolumn{2}{|c|}{$\begin{array}{l}\text { 4. USQ Required? } \\
\text { Yes } \bigcirc \text { No }\end{array}$} & \multirow{2}{*}{$\begin{array}{l}\text { 5. Date } \\
5 / 30 / 00 \\
\text { 8. Approval Designator } \\
5 N\end{array}$} \\
\hline & $\begin{array}{l}\text { 6. Project Title/No.Mork Order No. } \\
\text { Cold Vacuum Drying Facility } W-441\end{array}$ & \multicolumn{3}{|c|}{$\begin{array}{l}\text { 7. Bidg./Sys./Fac. No. } \\
142 \mathrm{~K}\end{array}$} & \\
\hline & $\begin{array}{l}\text { 9. Document Numbers Changed by this ECN (includes } \\
\text { sheet no. and rev.) } \\
\text { SNE-3087, Rev. } 1\end{array}$ & \multicolumn{3}{|c|}{$\begin{array}{l}\text { 10. Related ECN No(s). } \\
\text { n/a }\end{array}$} & $\begin{array}{l}\text { 11. Related PO No. } \\
\text { n/a }\end{array}$ \\
\hline $\begin{array}{l}\text { 12a. Modification Work } \\
\text { Yes (fill out Blk. 12b) } \\
\text { No }\left(\begin{array}{c}\text { NA B B ks. } 12 b \\
\text { 2c, 12d) }\end{array}\right.\end{array}$ & \multicolumn{3}{|c|}{\begin{tabular}{|l|l} 
12b. Work Package No. & $\begin{array}{l}12 \mathrm{c} . \text { Modification Work Completed } \\
\mathrm{n} / \mathrm{a}\end{array}$ \\
\end{tabular}} & \multicolumn{2}{|c|}{$\begin{array}{l}\text { 12d. Restored to Original Condition (Temp. } \\
\text { or Standby ECNs only) } \\
\mathrm{n} / \mathrm{a} \\
\text { Design Authority/Cog. Engineer Signature \& }\end{array}$} \\
\hline \multicolumn{6}{|c|}{$\begin{array}{l}\text { Changes include: } \\
\text { - Include addition of VPSCHW-PCV-7075 to text and figures } \\
\text { - Revise Figure 4-1 to reflect the current design. } \\
\text { - Add additional references and reformat appendix A. } \\
\text { - Add appendix D to include a record of future changes. } \\
\text { - Miscellaneous editorial corrections. }\end{array}$} \\
\hline
\end{tabular}

USQ Screening Number: CVD-00-1031 $10 B$ 6\% $\% 100$
Criteria Change
O Update of SDD reflects the current system design. Appendices revised to
Design Improvement
$O$ include additional documentation applicable to this SDD and to provide
Environmental
history for the VPSCHW system.
Facility Deactivation
0
As-Found
0
Facilitate Const.
0
Const. Error/Omission
Design Error/Omission

15. Distribution (include name, MSIN, and no. of copies)

See distribution sheet

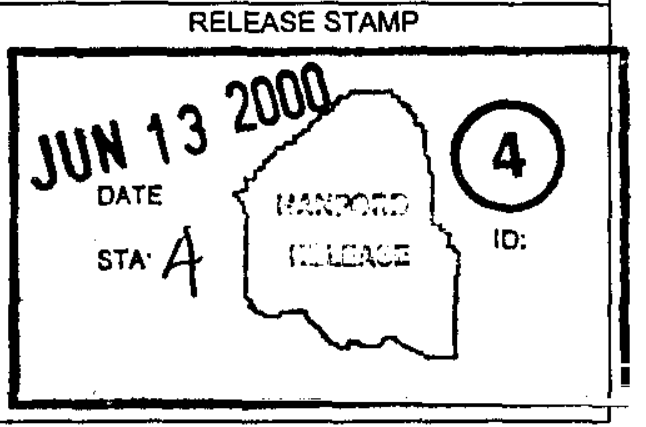




\section{ENGINEERING CHANGE NOTICE}

16. Design Verification $\quad$ 17. Cost Impact

Required

OYes

ONo
ENGINEERING

Additional $\bigcirc \$ n / a$

Savings $\bigcirc \$ n / a$
Page 2 of 2

1. ECN (use no. from pg. 1) 660509

18. Schedule Impact (days)

\section{CONSTRUCTION}

Additional $\bigcirc \$ n / a$

Savings
Improvement

Delay$$
\text { O }
$$

O

19. Change Impact Review: Indicate the related documents (other than the engineering documents identified on Side 1) that will be affected by the change described in Block 13. Enter the affected document number in Block 20.

\section{SDD/DD}

Functional Design Criteria

Operating Specification

Criticality Specification

Conceptual Design Report

Equipment Spec.

Const. Spec.

Procurement Spec.

Vendor Information

OM Manual

FSAR/SAR

Safety Equipment List

Radiation Work Permit

Environmental /mpact Statement

Envirgantental Report

Environmental Permit $\square$
$\square$
$\square$
$\square$
$\square$
$\square$
$\square$
$\square$
$\square$
$\square$
$\square$
$\square$
$\square$
$\square$
$\square$
Seismic/Stress Analysis

Stress/Design Report

Interface Control Drawing

Calibration Procedure

Installation Procedure

Maintenance Procedure

Engineering Procedure

Operating hrstruction

Operating Procedure

Operational Safety Requirement

IEFD Drawing

Cell Arrangement Drawing

Essential Material Specification

Fac. Proc. Samp. Schedule

Inspection Plan

Inventory Adjustment Request

20. Other Affected Documents: (NOTE: Documents listed below will not be revised by this ECN.) Signatures beiow indicate that the signing organization has been notified of other affected documents listed below.

Document Number/Revision

Document Number/Revision

None

\section{Approvals}

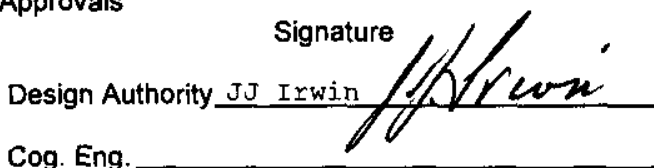

Cog. Eng.

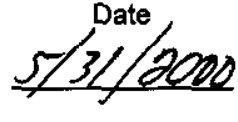

Cog. Mgr. T Choho

QA HM chasin Haulem.Chabic 5-31-0 Safety N I. Breh m folmaxisuim $6 / 12 / 00$ Environ.

other $*$ <. 5 .

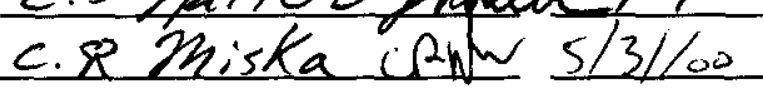

* APPROVAL AUTHORIZES

PARALLEL PREPARATION OF

USA SGREEYWHTH

MMPLEMENTATION OF 3 M

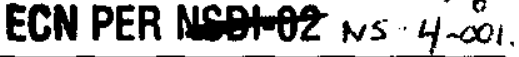

Document Number/Revision

Design Agent

PE

QA

Safety

Design

Environ.

Other

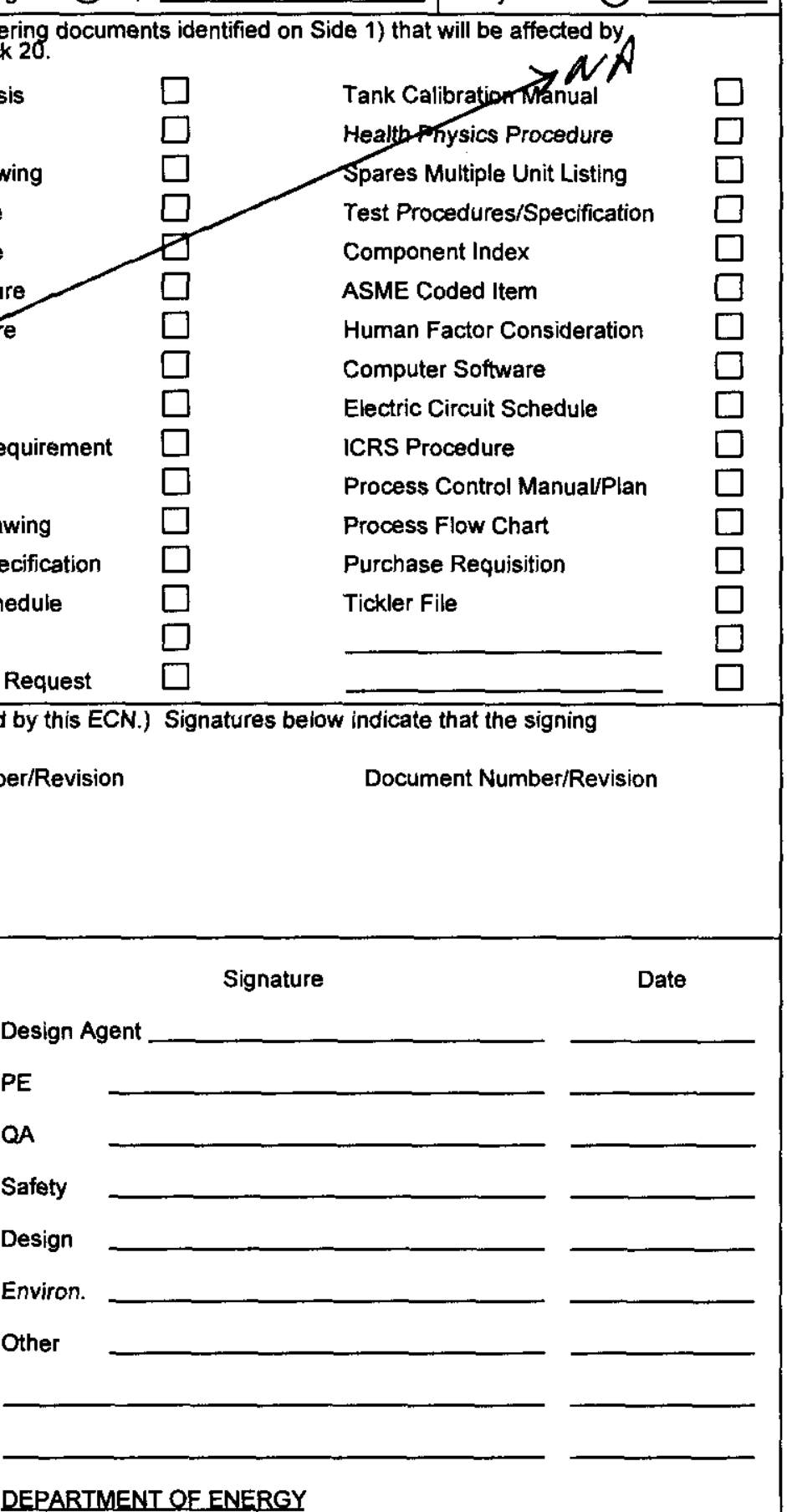

\section{OF ENERGY}

Signature or a Control Number that tracks the Approval Signature

ADDITIONAL 


\title{
Cold Vacuum Drying Facility Vacuum Purge System Chilled Water System Design Description
}

\author{
J. J. Irwin
}

Fluor Hanford

Date Published

May 2000

Prepared for the U.S. Department of Energy

Assistant Secretary for Environmental Management

Project Hanford Management Contractor for the

U.S. Department of Energy under Contract DE-AC06-96RL13200

Fluor Hanford

P.O. Box 1000

Richland, Washington
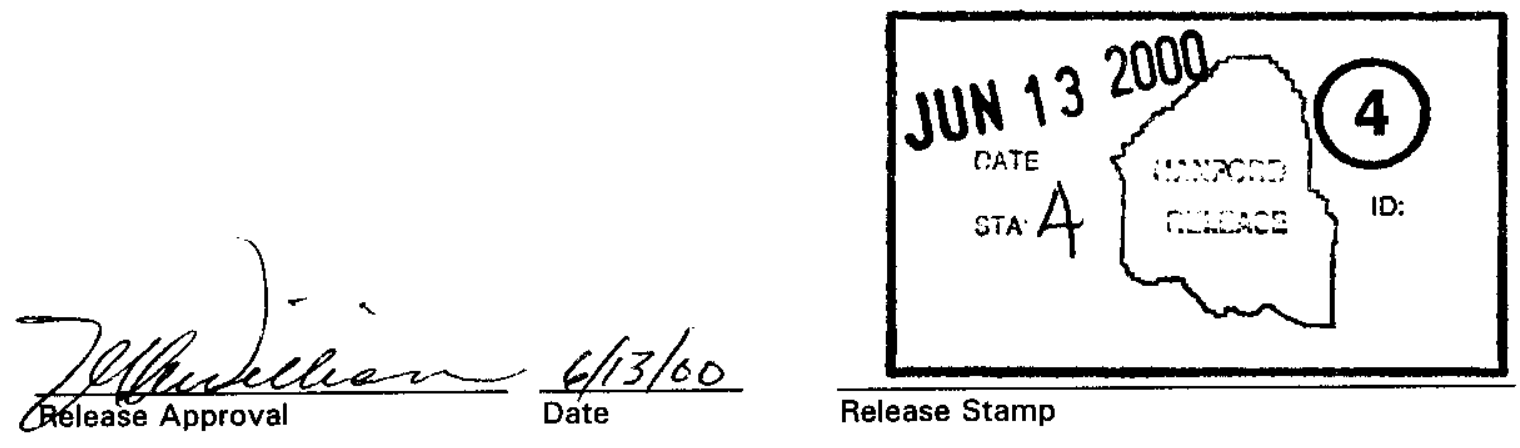


\section{Cold Vacuum Drying Facility Vacuum Purge System Chilled Water System Design Description}

Prepared for the U.S. Department of Energy

Assistant Secretary for Environmental Management

Project Hanford Management Contractor for the

U.S. Department of Energy under Contract DE-AC06-96RL.13200

Fluor Hanford

P.O. Box 1000

Richland, Washington 
LEGAL DISCLAIMER

This report was prepared as an account of work sponsored by an agency of the United States Government. Neither the

United States Government nor any agency thereof, nor any of their employees, nor any of their contractors, subcontractors or their employees, makes any warranty, express or implied, or assumes any legal liability or responsibility for the accuracy, completeness, or any third party's use or the results of such use of any information, apparatus, product, or process disclosed, or represents that its use would not infringe privately owned rights. Reference herein to any specific commercial product, process, or service by trade name, trademark, manufacturer, or otherwise, does not necessarily constitute or imply its endorsement, recommendation, or favoring by the United States Government or any agency thereof or its contractors or subcontractors. The views and opinions of authors expressed herein do not necessarily state or reflect those of the United States Government or any agency thereof.

This report has been reproduced from the best available copy.

Printed in the United States of America

Total Pages: $\mathrm{HO}$ 
RECORD OF REVISION

(2) Title

Cold Vacuum Drying Facility Vacuum Purge System Chilled Water System Design Description

CHANGE CONTROL RECORD

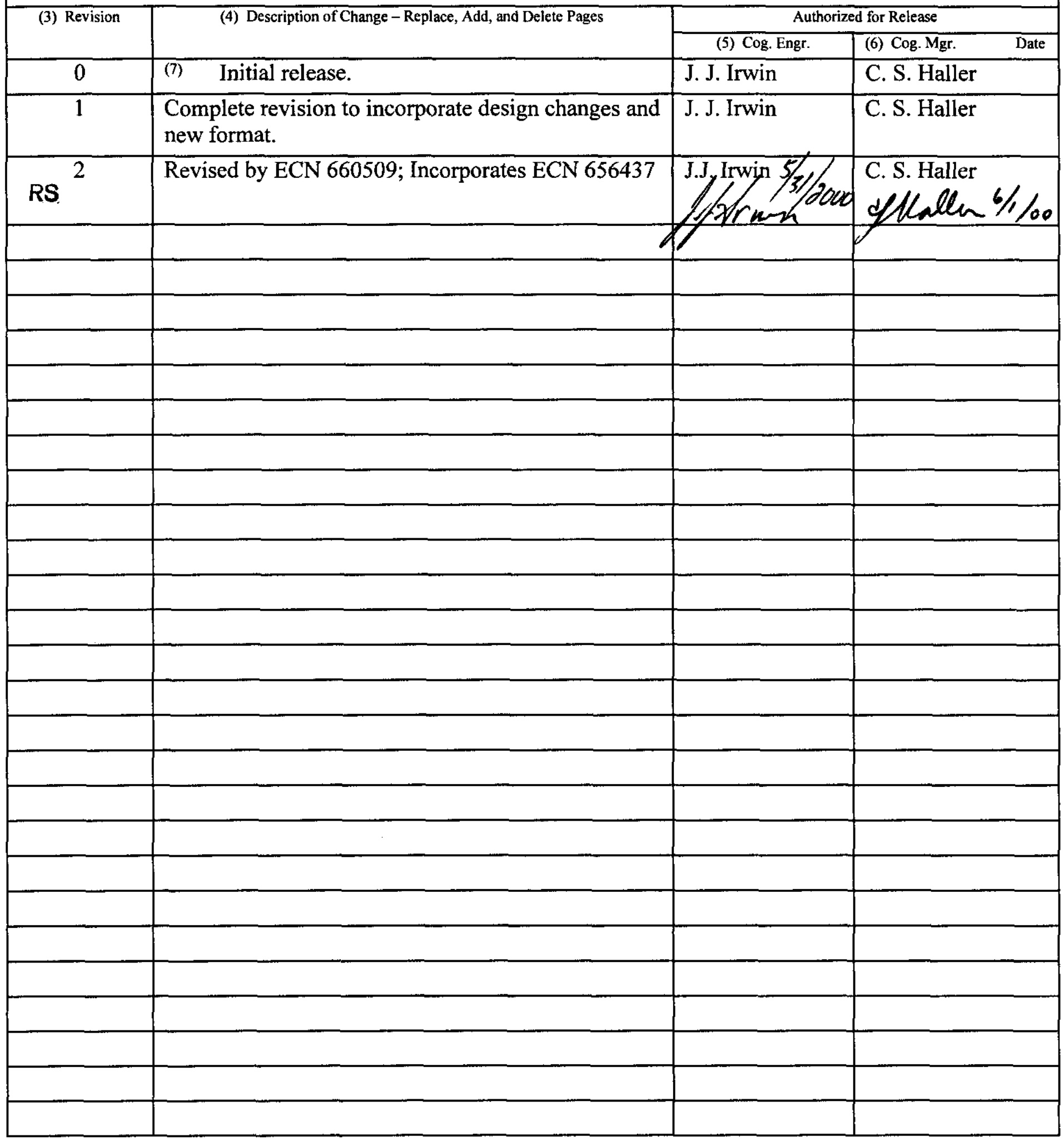


SYSTEM $47-4$ 


\section{TABLE OF CONTENTS}

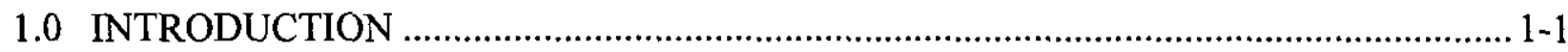

1.1 System Identification ............................................................................................

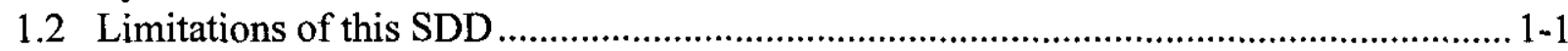

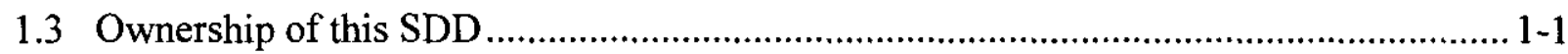

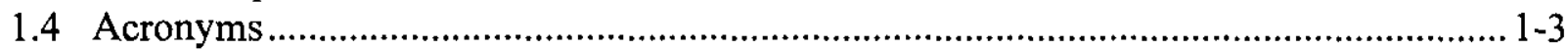

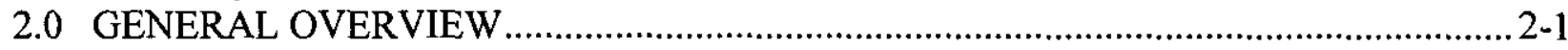

2.1 System Functions .................................................................................................. 2-1

2.1.1 Normal Process Functions ................................................................................ 2-1

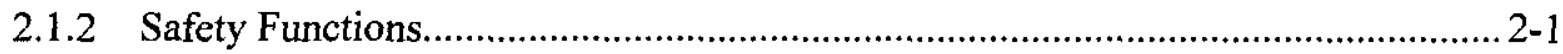

2.2 System Classification................................................................................................. 2-1

2.3 Basic Operational Overview ...................................................................................... 2-1

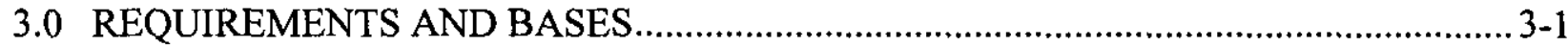

3.1 General Requirements.............................................................................................. 3-1

3.1.1 System Functional Requirements ……............................................................... 3-1

3.1.2 Subsystem and Major Components ………............................................................ 3-3

3.1.3 Boundaries and Interfaces............................................................................... 3-3

3.1.4 Codes, Standards, and Regulations ................................................................ 3-4

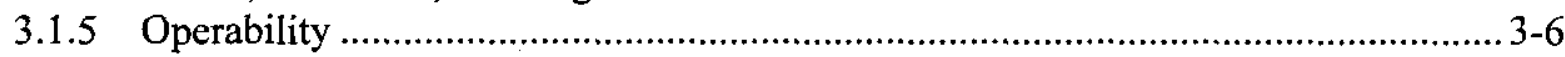

3.2 Special Requirements........................................................................................... 3-6

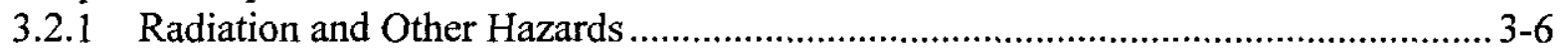

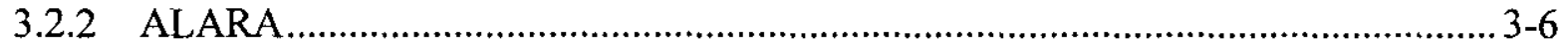

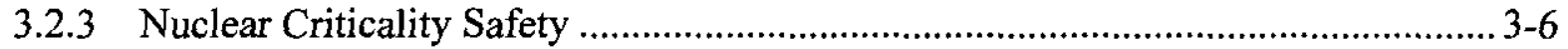

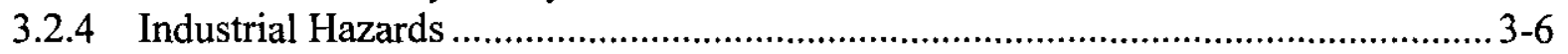

3.2.5 Operating Environment and Natural Phenomena ............................................. 3-6

3.2.6 Human Interface Requirements ........................................................................ 3-6

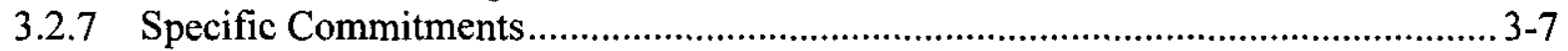

3.3 Engineering Disciplinary Requirements ....................................................................

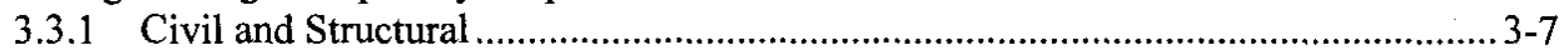

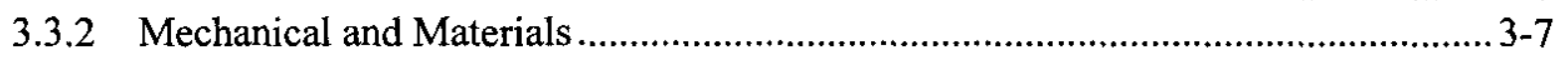

3.3.3 Chemical and Process ......................................................................................... 3-7

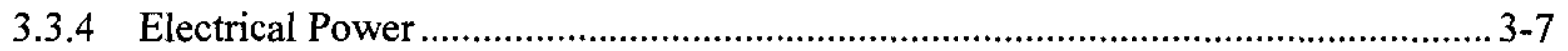

3.3.5 Instrumentation and Control ............................................................................. 3-7

3.3.6 Computer Hardware and Software .......................................................................

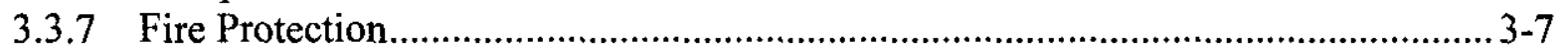

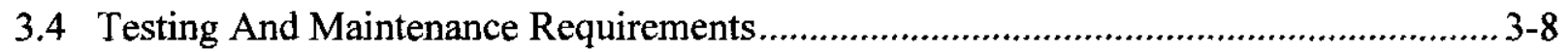

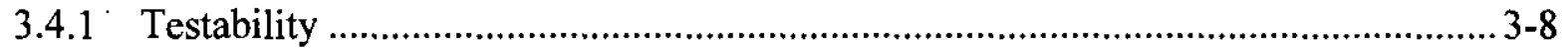

3.4.2 Technical Safety Requirement-Required Surveillances ....................................... 3-8

3.4.3 Non-Technical Safety Requirement Inspections and Testing ............................... 3-8

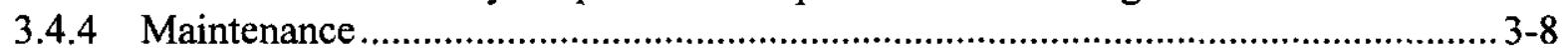




\section{SNF-3087 REV 2}

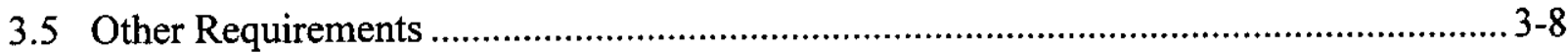

3.5.1 Security and Special Nuclear Material Protection ................................................ 3-8

3.5.2 Special Installation Requirements......................................................................... 3-8

3.5.3 Reliability, Availability, and Preferred Failure Modes.............................................. 3-9

3.5.4 Quality Assurance ............................................................................................... 3-9

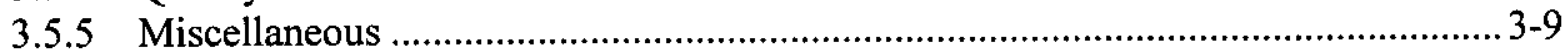

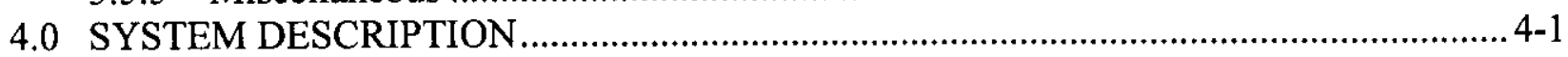

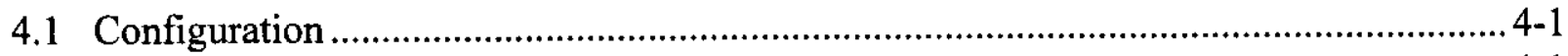

4.1.1 Description of System, Subsystems, and Major Components .................................. 4-1

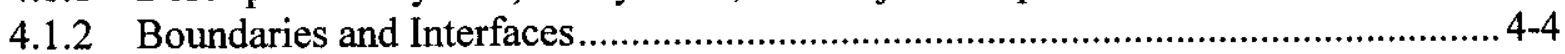

4.1.3 Physical Location and Layout...............................................................................

4.1.4 Principles of Operation ..................................................................................... 4-4

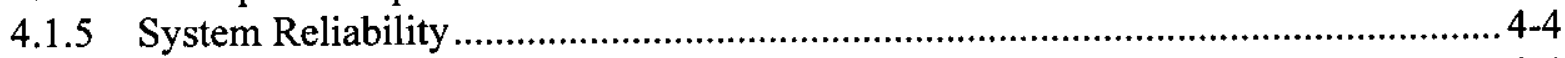

4.1.6 System Control Features .................................................................................... 4-4

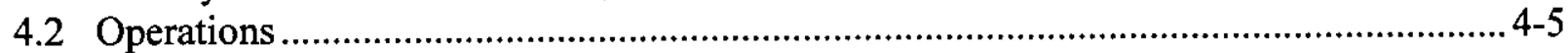

4.2.1 Initial Configurations (Pre-startup) ...................................................................... 4-5

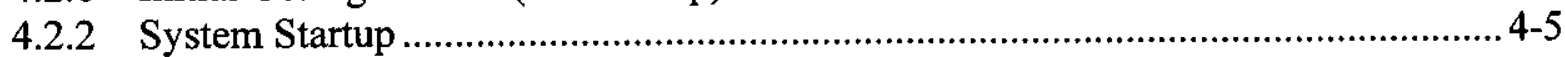

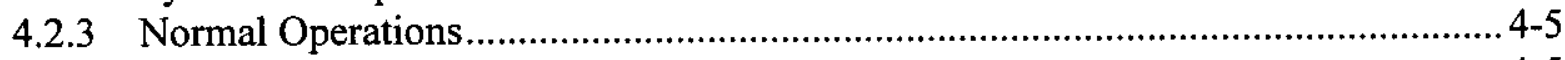

4.2.4 Off-Normal Operations .................................................................................. 4-5

4.2.5 System Shutdown ............................................................................................ 4-5

4.2.6 Safety Management Programs and Administrative Controls................................... 4-5

4.3 Testing And Maintenance ............................................................................................. 4-5

4.3.1 Temporary Configurations ................................................................................... 4-6

4.3.2 Technical Safety Requirement-Required Surveillances ........................................... 4-6

4.3.3 Non-Technical Safety Requirement Inspections and Testing ................................. 4-6

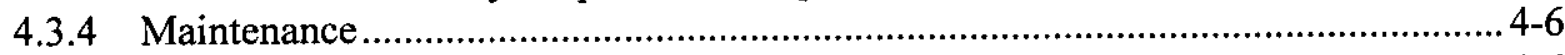

4.3.5 Equipment Calibration ...................................................................................... 4-6

APPENDIX A - Source Documents.................................................................................... A-1

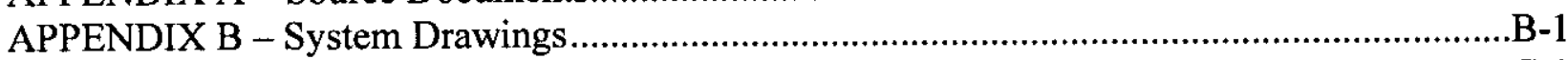

APPENDIX C - System Procedures...........................................................................................

APPENDIX D - System History ………………………..................................................... D-1 
SNF-3087 REV 2

\section{LIST OF FIGURES}

Figure 1-1. Vacuum Purge System Chilled Water................................................................ 1-2

Figure 2-1. Layout of Vacuum Purge System Chilled Water ................................................2 2-2

Figure 4-1. Vacuum Purge System Chilled Water.................................................................. 4-2 


\subsection{INTRODUCTION}

\subsection{System Identification}

This system design description (SDD) addresses the Vacuum Purge System Chilled Water (VPSCHW) system. The discussion that follows is limited to the VPSCHW system and its interfaces with associated systems. The reader's attention is directed to Drawings H-1-82162, Cold Vacuum Drying Facility Process Equipment Skid P\&ID Vacuum System, and H-1-82224, Cold Vacuum Drying Facility Mechanical Utilities Process Chilled Water P\&ID. Figure 1-1 shows the location and equipment arrangement for the VPSCHW system.

The VPSCHW system provides chilled water to the Vacuum Purge System (VPS). The chilled water provides the ability to condense water from the multi-canister overpack (MCO) outlet gases during the $\mathrm{MCO}$ vacuum and purge cycles. By condensing water from the MCO purge gas, the VPS can assist in drying the contents of the MCO.

\subsection{Limitations of this SDD}

This SDD, when used in conjunction with the other elements of the definitive design package, provides a complete picture of the VPSCHW for the CVD Facility. Elements of SDD include functions, requirements, and descriptions. Other documents comprising the definitive design include:

- $\quad$ Project design requirements (HNF-SD-SNF-DRD-002),

- $\quad$ Fire Hazard Analysis (HNF-SD-SNF-FHA-003),

- Master Equipment List (SNF-4148),

- CVDF Data and Calculation Database (SNF-3001),

- Construction Specification for Project W-441, (SNF-6209), Section 15400,

Plumbing/Piping, Section 15510, Chilled Water Piping and Specialty Items, and Section 15681, Single Package Process Chiller

- Technical Safety Requirements (HNF-3673).

- $\quad$ Final Safety Analysis Report (HNF-3553) Annex B.

\subsection{Ownership of this SDD}

The cold vacuum drying (CVD) Design Authority assigned to the CHW system is responsible for the accuracy and technical content of this SDD. Any questions on the system or content of this document shall be resolved through the design authority. 
Figure 1-1. Vacuum Purge System Chilled Water

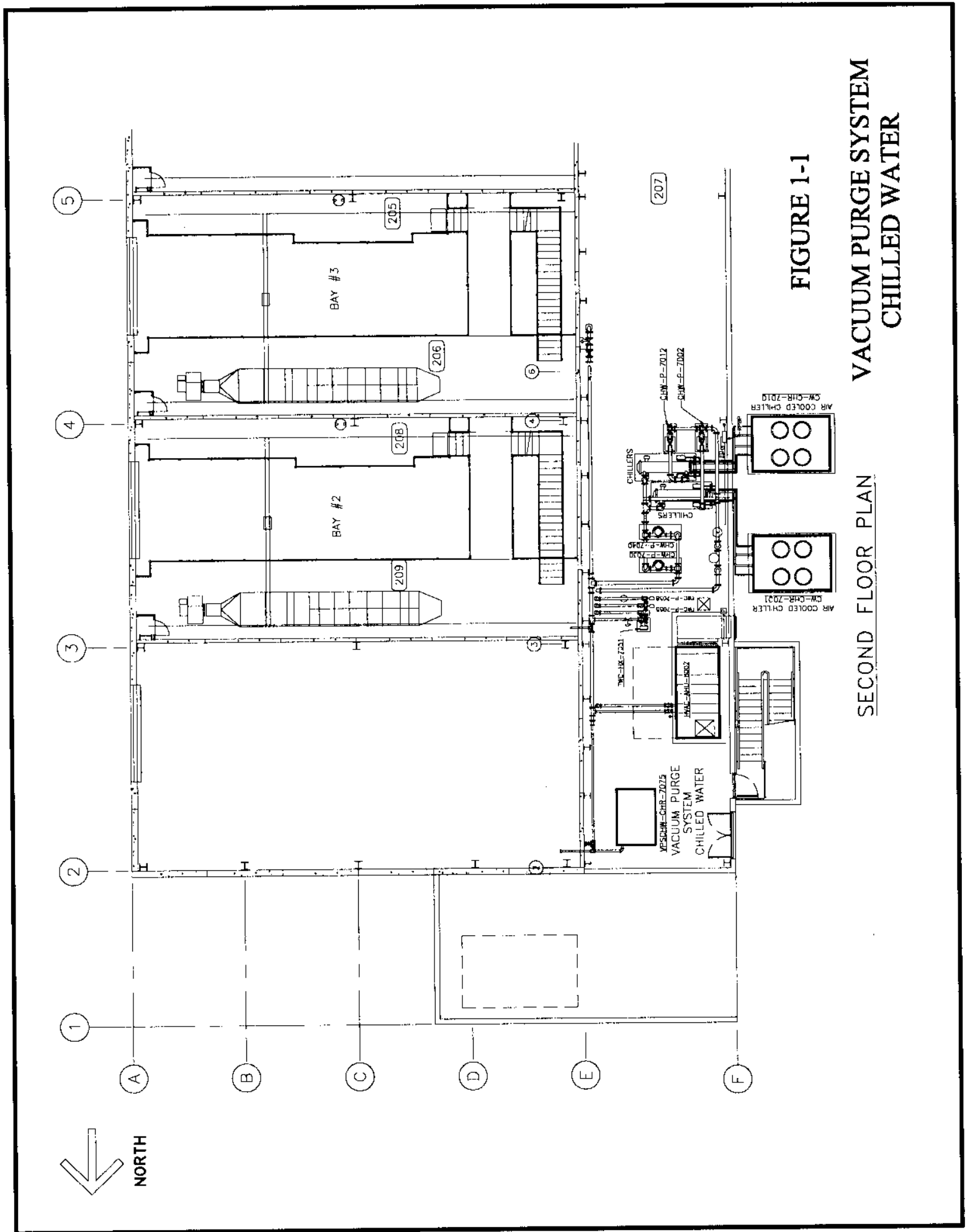




\subsection{Acronyms}

$\begin{array}{ll}\text { ANSI } & \text { American National Standards Institute } \\ \text { ASME } & \text { American Society of Mechanical Engineers } \\ \text { CVD } & \text { Cold Vacuum Drying } \\ \text { DOE } & \text { U.S. Department of Energy } \\ \text { DRD } & \text { Design Requirements Document } \\ \text { MCO } & \text { Multi-Canister Overpack } \\ \text { MCS } & \text { Monitoring and Control System } \\ \text { PCV } & \text { Pressure Control Valve } \\ \text { SAR } & \text { Safety Analysis Report } \\ \text { SNF } & \text { Spent Nuclear Fuel } \\ \text { VPS } & \text { Vacuum Purge System } \\ \text { VPSCHW } & \text { Vacuum Purge System Chilled Water }\end{array}$




\subsection{GENERAL OVERVIEW}

This section provides a general overview of the VPSCHW system. Section 2.1 describes the system functions. Section 2.2 states the VPSCHW system classification and Section 2.3 outlines the basic operation of the VPSCHW system.

\subsection{System Functions}

\subsubsection{Normal Process Functions}

The VPSCHW system provides chilled water to the Vacuum Purge System (VPS). The chilled water supply for the VPS is a dedicated, low-temperature chiller (one chiller package for the four process bays, no redundancy). This chiller is capable of supplying chilled water to all condensers. The VPS uses the chilled water in the condensation of water during gas purge and vacuum pumping, phases of the VPS operation.

In the following descriptions, an asterix $(*)$ appears in the piping line, component, and instrument tag numbers. The asterix denotes the CVDF bay number in which the piping line, component, or instrument resides. For example, GOV-1*01 represents valves GOV-1301 (not installed), GOV-1401, and GOV-1501 in process bays three through five. All component or instrument tag number with a zero in the second digit reside in a common area within the CVDF.

\subsubsection{Safety Functions}

There are no safety functions listed in Chapter 4 of the CVD Facility Final Safety Analysis Report (FSAR) for the VPSCHW system.

\subsection{System Classification}

The VPSCHW system is designated as general service.

\subsection{Basic Operational Overview}

This section gives a brief discussion of how the VPSCHW system operates. Figure 2-1 provides a simplified diagram of the VPSCHW system.

The VPSCHW system is used to supply chilled water at design temperature and flow rate to the VPS condenser and VPS condenser receiver tank cooling jacket. The system condenses water during the vacuum pumping operational phase and dries the gas stream during the gas purge or recirculation operational phase. A flow control valve controls the flow of chilled water without intervention from the Monitoring and Control System (MCS). The VPSCHW system chiller is normally operated continuously during VPS operations. 
Figure 2-1. Layout of Vacuum Purge System Chilled Water

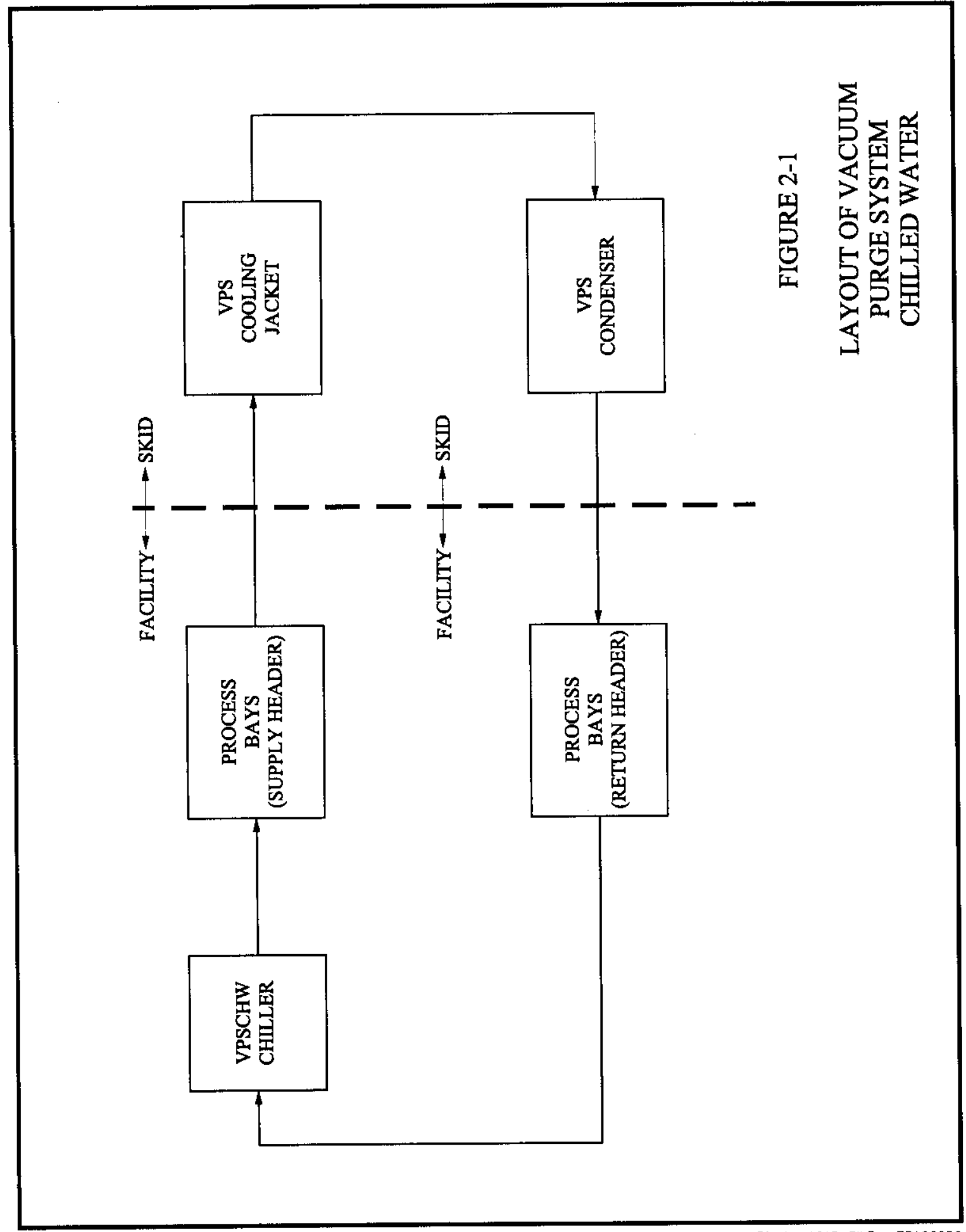


SNF-3087 REV 2

\subsection{REQUIREMENTS AND BASES}

\subsection{General Requirements}

Operational and functional requirements are taken from HNF-SD-SNF-DRD-002, Cold Vacuum Drying Facility Design Requirements, Section 6.0, "Process System Design Requirements."

\subsubsection{System Functional Requirements}

\subsubsection{Design Requirements}

The following describes the performance requirements, basis for those requirements, and how the requirement is met by the VPSCHW system. The requirements are drawn from HNF-SDSNF-DRD-002, Cold Vacuum Drying Facility Design Requirements.

1. Requirement: The VPS chilled water system shall supply chilled water at design temperature and flow rate to the VPS condenser and to the VPS rundown tank loading jacket. The system concept shall include packaged chiller units, circulating pumps, and associated piping, instrumentation, and controls.

Basis: HNF-SD-SNF-DRD-002, Rev. 4, Sections 2.2.9 and 6.6.4.2. The use of a single chilled water cooling system to supply the VPS condensers minimizes the equipment, piping, and instrumentation required.

How the system meets the requirement: The system design as identified in the design media implement this requirement. See Drawings H-1-82162 and H-1-82224.

2. Requirement: Chillers shall meet applicable American Refrigeration Institute (ARI) standards and have the minimum controls specified in DOE 64301.1A, Section 15502.1.2.

Basis: HNF-SD-SNF-DRD-002, Rev. 4, Section 6.6.4.2.b. Design of a process chiller is included in the scope of ANSI/ARI 550, Centrifugal or Rotary Screw Water Chilling Packages; ANSI/ARI 590, Reciprocating Water Chilling Packages; and U.S. Department of Energy (DOE) Order 6430.1A. This code was specified to ensure standardization of design and construction and to ensure operator safety.

How the system meets the requirement: Chillers meet ARI standards and have the minimum controls specified in DOE Order 6430.1A, Section 1550-2.1.2. The packaged chiller is designed to meet these standards as per CVD Facility Construction Specification Section 15681, "Single Package Process Chiller."

3. Requirement: Expansion tanks shall be designed to the ASME Code, Section VIII, and shall include gauge glasses, drain valves, vent valves, and pressure relief valves. 


\section{SNF-3087 REV 2}

Basis: HNF-SD-SNF-DRD-002, Rev. 4, Section 6.6.4.2.c. These instruments and valves prevent damage to the system.

How the system meets the requirement: Chillers include gauge glasses, drain valves, vent valves, and pressure relief valves. The package chiller is designed to include these components as per CVD Facility Construction Specification Section 15681, "Single Package Process Chiller."

4. Requirement: Make-up water shall be drawn from the potable water supply through a reduced pressure backflow assembly.

Basis: HNF-SD-SNF-DRD-002, Rev. 4, Section 6.6.4.2. The backflow assembly prevents the VPSCHW system water from contaminating the potable water system.

How the system meets the requirement: Make-up water for the chilled water system is drawn from the potable water supply through a reduced pressure backflow assembly. There is no direct connection between the potable water system and the chiller. The water/glycol mixture will be transferred to the VPSCHW system utilizing a charging pump (system 100) with a self contained tank.

5. Requirement: All chilled water piping shall be designed and constructed in accordance with ASME B31.3 (process skids) or B31.9 (facility).

Basis: HNF-SD-SNF-DRD-002, Rev. 4, Section 6.6.4.2.f. Design of a chilled water piping system is included in the scope of ANSI/ASME B31.3, B31.5, or B31.9. This code was specified to ensure standardization of design and construction, and to ensure operator safety.

How the system meets the requirement: All chilled water piping is designed and constructed in accordance with ANSI/ASME B31.3 or ANSI/ASME B31.9. The chilled water piping installation conforms to ANSI/ASME B31.9.

6. Requirement: All refrigerant piping shall be designed and constructed in accordance with ASME B31.5.

Basis: HNF-SD-SNF-DRD-002, Rev. 4, Section 6.6.4.2.c.

How the system meets the requirement: The construction specification Section 15681, "Single Package Process Chiller," requires refrigerant piping be designed and constructed according to ANSI/ASME B31.5.

7. Requirement: Chilled water shall not come in direct contact with process equipment surfaces, such as the MCO, that might be contaminated.

Basis: HNF-SD-SNF-DRD-002, Rev. 4, Section 6.6.4.2.a. The use of intermediate cooling systems between the MCO and the chilled water system minimizes the likelihood 


\section{SNF-3087 REV 2}

that the facility systems can become contaminated. Therefore, any contamination is isolated within the process bays.

How the system meets the requirement: The system is such that chilled water does not come in direct contact with potentially contaminated process equipment surfaces, such as the MCO. Chilled water in the VPSCHW system interfaces with the VPS section through a condenser and condenser rundown tank. The VPSCHW circulates water through a cooling jacket (ASME section VIII coded vessel) attached to the VPS condenser tank (ASME section VIII coded vessel). The water is then circulated through the VPS condenser (ASME section VIII coded vessel) which is a flat plate heat exchanger with physically separate chamber for the chilled water and the process stream The VPS interfaces with the MCO. There is no direct physical interface between the VPSCHW system and the MCO.

\subsubsection{Safety Requirements}

3.1.1.2.1 Safety Class Requirements. There are no safety class requirements for the VPSCHW system.

3.1.1.2.2 Safety Significant Requirements. There are no safety significant requirements for the VPSCHW system.

3.1.1.2.3 Other Safety Requirements. There are no other safety requirements for the VPSCHW system.

3.1.1.3 Environmental Requirements. There are no environmental requirements for the VPSCHW system.

3.1.1.4 Mission-Critical Requirements. There are no mission-critical requirements for the VPSCHW system.

\subsubsection{Operability.}

\subsubsection{Subsystem and Major Components}

All VPSCHW system tank, valves, components, instrumentation, and controls are designated general service and are designed and qualified for performance category 1 .

\subsubsection{Boundaries and Interfaces}

The VPSCHW system interfaces with a number of different components throughout the CVD Facility, but has no interface or boundary requirements identified. 


\section{SNF-3087 REV 2}

\subsubsection{Codes, Standards, and Regulations}

\subsubsection{Code of Federal Regulations}

- 10 CFR 830.120, "Quality Assurance"

- 29 CFR 1910.120, "Occupational Safety and Health Standards"

\subsubsection{American Society of Mechanical Engineers (ASME)}

- B16.5, Pipe Flanges and Flanged Fittings (ANSI-approved)

- B16.9, Building Services Piping

- B16.10, Face to Face and End to End Dimensions of Valves

- B16.11, Forged Steel Fittings, Socket-Welding and Threaded (ANSI-approved)

- B16.21, Nonmetallic Flat Gaskets for Pipe Flanges

- B16.25, Buttwelding Ends

- B16.34, Valves Flanged, Threaded, and Welding End

- B16.39, Malleable Iron Threaded Pipe Unions Classes 150, 250, and 300 (ANSI-approved)

- B18.2.1, Square and Hex Bolts and Screws Inch Series Including Hex Cap Screws and Lag Screws (ANSI-approved)

- B31.3, Process Piping

- B31.5, Refrigeration Piping

- B31.9, Building Services Piping

Boiler and Pressure Vessel Code

- Section II, "Material Specifications, Welding Rods, Part C Electrodes, and Filler Metals"

- Section VIII, "Division I Rules for Construction of Pressure Vessels"

- Section IX, "Qualification Standard for Welding and Brazing Procedures, Welders, Brazers, and Welding and Brazing Operators" 


\section{SNF-3087 REV 2}

\subsubsection{American Society of Nondestructive Testing}

- SNT-TC-1A, Recommended Practice

\subsubsection{American Society for and Materials}

- A36, Standard Specification for Structural Steel

- A105, Standard Specification for Forgings, Carbon Steel, for Piping Components

- A106, Standard Specification for Seamless Carbon Steel Pipe for High-Temperature Service

- A240, Standard Specification for Heat-Resisting Chromium and Chromium-Nickel Stainless Steel Plate, Sheet, and Strip for Pressure Vessels

- A269, Standard Specification for Seamless and Welded Austenitic Stainless Steel Tubing for General Service

- A276, Standard Specification for Stainless and Heat-Resisting Steel Bars and Shapes

- A307, Standard Specification for Carbon Steel Bolts and Studs, 60,000 PSI Tensile Strength

- A312/312M, Standard Specification for Seamless and Welded Austenitic Stainless Steel Pipes

- A354, Standard Specification for Quenched and Tempered Alloy Steel Bolts, Studs and Other Externally Threaded Fasteners

- A403, Standard Specification for Wrought Austenitic Stainless Steel Piping Fittings

- A479, Standard Specification for Stainless and Heat-Resisting Steel Bars and Shapes for Use in Boilers and other Pressure Vessels

- A480, Standard Specification for General Requirements for Flat-Rolled Stainless HeatResisting Steel Plate, Sheet, and Strip

- A500, Standard Specification for Cold-Formed Welded and Seamless Carbon Steel Structural Tubing in Rounds and Shapes.

\subsubsection{American Welding Society}

- D1.1, Structural Welding Code - Steel 


\section{SNF-3087 REV 2}

3.1.4.6 DOE Standards. All VPSCHW pumps, tank, valves, instrumentation, controls, and support structures required to perform the general services are designed and qualified for performance category 1 as defined in DOE-STD-1021, Natural Phenomena Hazards Design and Evaluation Criteria for Department of Energy Facilities.

\subsubsection{National Equipment Manufacturers Association}

- NFPA-250, Enclosures for Electrical Equipment

\subsubsection{National Fire Protection Association}

- NFPA-70, National Electrical Code

\subsubsection{Operability}

There are no operability requirements for the VPSCHW system.

\subsection{Special Requirements}

\subsubsection{Radiation and Other Hazards}

There are no radiation and other hazards requirements for the VPSCHW system.

\subsubsection{ALARA}

There are no as low as reasonably achievable (ALARA) requirements for the VPSCHW system.

\subsubsection{Nuclear Criticality Safety}

There are no criticality control requirements is for the VPSCHW system.

\subsubsection{Industrial Hazards}

There are no industrial hazards requirements for the VPSCHW system.

\subsubsection{Operating Environment and Natural Phenomena}

There are no operating environment or natural phenomena requirements for the VPSCHW system.

\subsubsection{Human Interface Requirements}

There are no human interface requirements for the VPSCHW system. The VPSCHW system operates in an automatic mode. Human interface is limited, but may include activation of the system, periodic surveillance, and maintenance functions. 


\section{SNF-3087 REV 2}

\subsubsection{Specific Commitments}

The VPSCHW system shall comply with the Hanford Federal Facility Agreement and Consent Order (Ecology 1994), and with applicable federal, state, and local laws, and American Indian treaty rights.

\subsection{Engineering Disciplinary Requirements}

\subsubsection{Civil and Structural}

All VPSCHW process equipment vessels and tanks shall be designed and fabricated per Boiler and Pressure Vessel Code (ASME 1995), Section VIII, "Rules for Construction of Pressure Vessels," Division 1, and Heat Exchangers Mechanical Standards (Tank Equipment Manufacturers Association 1992).

\subsubsection{Mechanical and Materials}

All VPSCHW process equipment piping and valves shall be designed and fabricated per ANSI/ASME B31.3, B31.5, or B31.9, Piping Codes, and ANSI/ASME B16 Standards series, Fittings, Flanges, and Valves.

\subsubsection{Chemical and Process}

There are no chemical and process requirements specific to the VPSCHW system.

\subsubsection{Electrical Power}

The electrical power supply provides reliable power for the VPSCHW system to operate.

\subsubsection{Instrumentation and Control}

There are no instrumentation and control requirements specific to the VPSCHW system.

\subsubsection{Computer Hardware and Software}

Computer hardware and software are covered under the SDD for the MCS (SNF-3090) and the Safety-Class Instrumentation and Control (SNF-3091) system.

\subsubsection{Fire Protection}

There are no fire protection requirements specific to the VPSCHW system. 


\section{SNF-3087 REV 2}

\subsection{Testing And Maintenance Requirements}

\subsubsection{Testability}

There are no testability requirements specific to the VPSCHW system. System design incorporates features for verifying system operability.

\subsubsection{Technical Safety Requirement-Required Surveillances}

There are no technical safety requirements required surveillances for the VPSCHW system.

\subsubsection{Non-Technical Safety Requirement Inspections and Testing}

Functional performance criteria are tested on a periodic basis to ensure operability of systems and components. All testing is performed between $\mathrm{MCO}$ processing cycles to the maximum extent possible, and has minimum impact on processing availability.

System operability is verified by surveillance of the system's operability status and component states (e.g. valve position, supply pressure, system alarms) initiating the CVD Facility process system verification for each $\mathrm{MCO}$ process cycle. The system requires additional periodic surveillance if required to be operational for an extended period of time beyond the three-year operating period.

The VPSCHW system has sufficient testability designed into it to permit the periodic measurement and calibration of all setpoints and adjustments that affect the manner in which the VPSCHW system performs. Periodic testing of VPSCHW structures, systems, and components (SSCs) is dictated by the requirements of the individual components according to the respective manufacturer's recommended schedule and practice

\subsubsection{Maintenance}

Regularly scheduled maintenance activities are avoided in the design. System maintenance activities are limited to maintenance caused by failures. System design incorporates features (e.g. sufficient working space around the component for repair or removal) for ease of maintenance. To the maximum extent possible, the design allows major components and energy sources to be easily isolated in order to meet lock and tag requirements.

\subsection{Other Requirements}

\subsubsection{Security and Special Nuclear Material Protection}

There are no security or SNM protection requirements for the VPSCHW system.

\subsubsection{Special Installation Requirements}

There are no special installation requirements to the VPSCHW system. 


\section{SNF-3087 REV 2}

\subsubsection{Reliability, Availability, and Preferred Failure Modes}

The VPSCHW stays online during the life of the project, and no maintenance activities are required during the CVD Facility three-year operating period.

\subsubsection{Quality Assurance}

The VPSCHW system fabrication quality assurance/control program is based on the safety classification of the SSCs as detailed in HNF-SD-SNF-SEL-002, Safety Equipment List; SNF4148, Master Equipment List; and application of a graded approach as described in HNF-MP599, Project Hanford Quality Assurance Program Description.

\subsubsection{Miscellaneous}

A conceptual decontamination and decommissioning plan for the CVD Facility, as identified in the guidelines of DOE-STD-3009-94, Preparation Guide for U.S. Department of Energy Nonreactor Nuclear Facility Safety Analysis Reports, is included in HNF-SD-SNF-SAR-002. 


\subsection{SYSTEM DESCRIPTION}

\subsection{Configuration}

\subsubsection{Description of System, Subsystems, and Major Components}

The VPSCHW system is a closed loop water/propylene glycol system supplied by VPSCHWCHR-7075. The major components of the VPSCHW system are a packaged chiller unit (VPSCHW-CHR-7075), copper tubing, a strainer, isolation valves, a pressure control valve, a relief valve, and instrumentation (i.e., pressure, temperature, flow). Chilled water is supplied to each VPS at the tank coolers (VPS-CLR-2*17) and condensers (VPS-COND-2*13) in series. Return water from condensers VPS-COND-2*13 are received by the chiller (see Figure 4-1). Chiller VPSCHW-CHR-7075 is a dedicated, low temperature chiller capable of supplying $4 \mathrm{gpm}$ of $2^{\circ} \mathrm{C}\left(35^{\circ} \mathrm{F}\right)$ water to each active process bay. Chiller VPSCHW-CHR-7075 consists of two pumps, a storage tank, a fill port, a chiller drain, and a bypass valve.

The following is a detailed discussion of the VPSCHW system.

Line VPSCHW-101-CT-1 1/4", connects the outlet of chiller VPSCHW-CHR-7075 to distribution header VPSCHW-501-CT-1 1/4". All lines are copper tubing except on the process skid. Lines on the process skid are stainless steel.

1. Safety relief valve VPSCHW-SRV-7081 on the chiller outlet relieves pressure in the line to a 20 liter plastic container if pressure exceeds 50 psig.

2. Isolation valve VPSCHW-V-075 in line VPSCHW-101-CT-1 1/4" can be used to isolate the chiller. This valve is normally open.

3. Pressure transmitter PT-7076 and associated control elements monitor the pressure of the chiller outlet water. An isolation valve VPSCHW-V-078 is provided for the pressure transmitter. After the PT, VPSCHW-V-081 provides a high point vent.

4. Temperature transmitter TT-7077 and associated control elements monitor the temperature of the chiller outlet water.

5. Flow element FE-7078 and associated control elements monitor the flow of the chiller outlet water. The section of copper tubing that contains the flow transmitter is increased from $1 \frac{1 / 4}{4}$ to $1 \frac{1 / 2 "}{2}$

6. Header VPSCHW-501-CT-1 1/4" connects line VPSCHW-101-CT-1 1/4" to each supply line, VPSCHW-*01-CT-1", to the process bays. There are 5 branch connections from the supply header, one for each process bay. The following discussion follows a typical line in the VPSCHW system from the header to the VPSCHW chiller. Isolation valve VPSCHW-V-*75 is provided in the branch line to block flow to each process bay if needed but is normally open. VPSCHW-V-277 provides a high point vent for the supply header. 
Figure 4-1. Vacuum Purge System Chilled Water

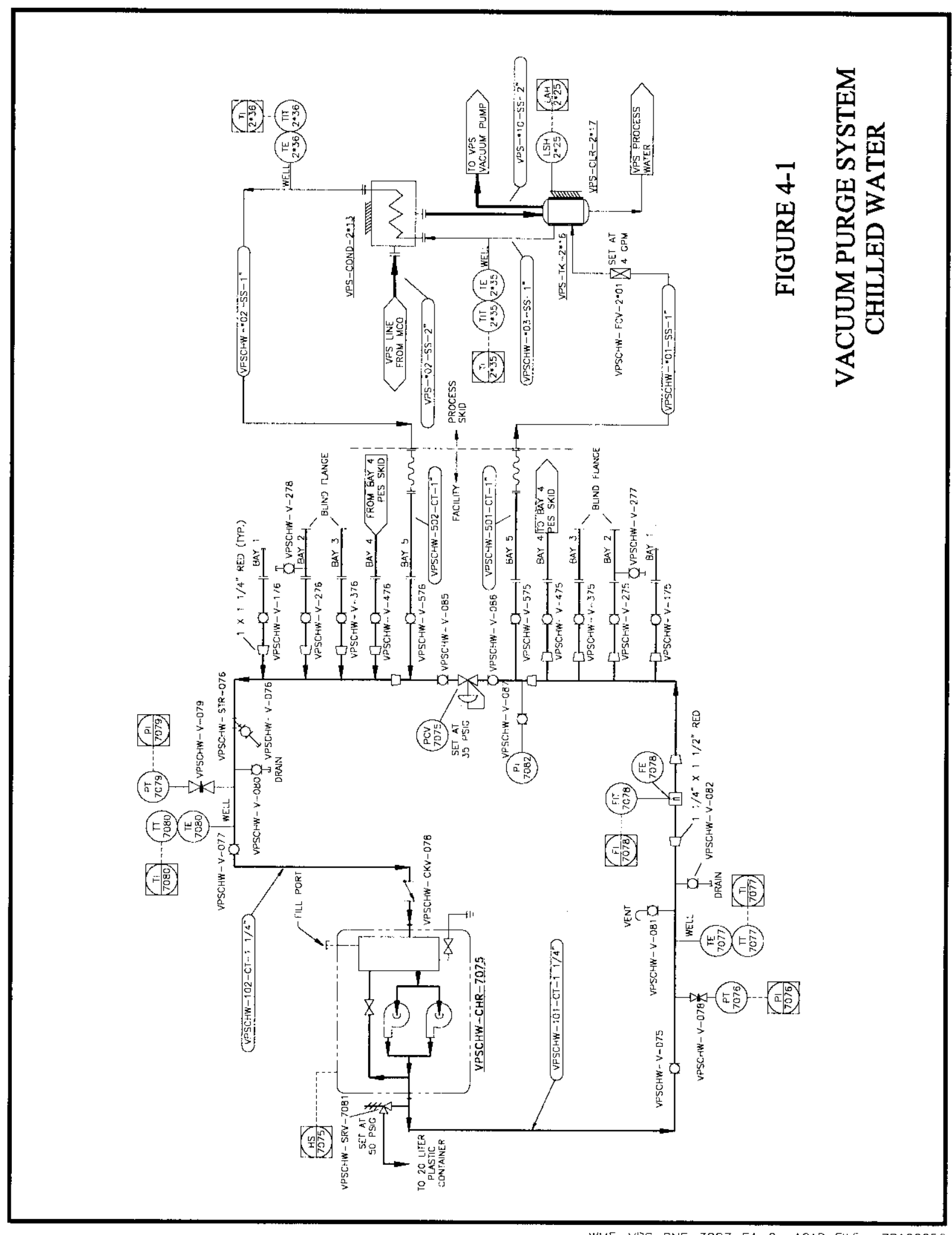

WUF: VPS_SNF-3087_F4-2 ACAD FILE: ZBACO056 
7. Line VPSCHW-*01-CT-1" transitions to VPSCHW-*01-SS-1" at the PES skid and this line then connects to VPS tank cooler VPS-CLR-2*17 on the process equipment skid. Flow control valve VPSCHW-FCV-2*01 is set to $4 \mathrm{gpm}$ to provide constant flow of chilled water to tank cooler VPS-CLR-2*17.

8. VPS-CLR-2*17 provides cooling for the condensed water recovered from the MCO vacuum and purge gases in tank VPS-TK-2*16. Line VPSCHW-*03-SS-1" connects tank cooler VPS-CLR-2*17 to condenser VPS-COND-2*13.

9. Temperature transmitter TIT $-2 * 35$ and associated control elements monitor the VPS condenser inlet temperature. TIT-2*35 is inserted in a thermowell in line VPSCHW-*03SS-1".

10. Condenser VPS-COND- $2 * 13$ condenses water from the MCO vacuum and purge gas. Line VPSCHW-*02-SS-1" connects the condenser outlet in the process bay to line VPSCHW-502-CT-1" at the PES interface.

11. Temperature transmitter TIT $-2 * 36$ and temperature indicator TI- $2 * 36$ monitor the temperature of the chilled water exiting the VPS condenser. TIT $-2 * 36$ is inserted in a thermowell in line VPSCHW-*02-SS-1"

12. Line VPSCHW-502-CT-1" connects line VPSCHW-*02-CT-1" to return header VPSCHW-502-CT-1 1/4". Isolation valve VPSCHW-V-*76 is provided in the return branch connection (VPSCHW-502-CT-1).

13. Header VPSCHW-502-CT-1 1/4" connects to line VPSCHW-102-CT-1 1/4". Line VPSCHW-102-CT-1 1/4" connects to the chiller. Strainer VPSCHW-STR-076 is provided in the return line. Header valve VPSCHW-V-076 connected to the strainer provides a way to flush the strainer and system.

14. Pressure transmitter PT-7079 and associated control elements monitor pressure at the chiller inlet. Pressure transmitter PT-7079 is isolated by valve VPSCHW-V-079. After the PT, VPSCHW-V-084 provides a high point vent.

15. Temperature transmitter TT-7080 and associated control elements monitor temperature at the chiller inlet.

16. An isolation valve VPSCHW-V-077 and a check valve VPSCHW-CKV-078 are provided in the return header to the chiller.

17. Pressure control valve VPSCHW-PCV-7075, set at $35 \mathrm{psig}$, regulates system pressure. If the pressure exceeds the setpoint due to isolation of the flow to the process bays, the valve will open to provide flow to the chiller pumps. Valves VPSCHW-V-085 and VPSCHW-V-086 isolate the pressure control valve. 


\section{SNF-3087 REV 2}

18. Pressure indicator PI-7082 is provided to allow calibration of VPSCHW-PCV-7075. An isolation valve, VPSCHW-V-087 is provided for the pressure indicator.

19. VPSCHW-V-278 provides a high point vent for the return header.

\subsubsection{Boundaries and Interfaces}

The following VPS condensers receive chilled water from the VPSCHW system:

- VPS-COND-2213 (future)

- VPS-COND-2313 (future)

- VPS-COND-2413

- VPS-COND-2513

The VPSCHW system interfaces with the MCS and all instrumentation and controls wiring is per ANSI/IEEE-603. All VPSCHW systems that interface with the CVDF electrical system are through hardwired connections with facility three-phase $480 \mathrm{~V}$ (ac) electrical. All wiring is installed according to ANSI/NFPA 70, National Electrical Code.

\subsubsection{Physical Location and Layout}

The VPSCHW system chiller is located in mechanical room 207. The system interfaces with the VPS condensers on the process equipment skid located in the process bays. Refer to Figure 1-1 for the locations of the VPSCHW system.

\subsubsection{Principles of Operation}

The VPSCHW system is used to supply chilled water at $2^{\circ} \mathrm{C}\left(35^{\circ} \mathrm{F}\right)$ and $4 \mathrm{gpm}$ to VPS condenser VPS-COND-2*13 and VPS condenser tank cooling jacket VPS-CLR-2*17. The system condenses water during the vacuum pumping operational phase and dries the gas stream during the gas purge or recirculation operational phase. Flow control valve VPSCHW-FCV-2*01 controls the flow at $4 \mathrm{gpm}$ without MCS intervention.

\subsubsection{System Reliability}

The VPSCHW system stays online during the life of the project and is designed for a operating life of five years.

\subsubsection{System Control Features}

4.1.6.1 System Monitoring. The VPSCHW system contains instrumentation and alarms that monitor system parameters. Instrumentation is described in Section 4.1.1. The MCS has no control functions over the VPSCHW.

4.1.6.2 Setpoints and Ranges. The setpoints and ranges for the system control features will be identified when available. 


\section{SNF-3087 REV 2}

\subsection{Operations}

The CVDF operation is a batch process. Operation of the VPSCHW itself is performed in conjunction with all the interface systems described in Section 4.1.2. For a detailed sequence of operations, see the operations manual (SNF-2356) and Appendix D of W-441-P003, The Fabrication and Procurement Specification for the Monitoring and Control System. Detailed operating steps are not presented here.

Test specifications and procedures have been developed to identify factory acceptance, construction acceptance, and pre-operational test procedures.

\subsubsection{Initial Configurations (Pre-startup)}

The initial configuration will be specified in the test specification.

\subsubsection{System Startup}

Startup procedures and alignments will be specified in the test specification.

\subsubsection{Normal Operations}

A VPSCHW normal operation is continuous operation of the chiller. The chiller has a constant flow of chilled water through the system independent of the required load. Operational procedures providing detailed information on operating modes and activities (including alarm response, shutdown, etc.) are listed in Appendix C.

\subsubsection{Off-Normal Operations}

Any time an alarm sounds from the pressure or temperature sensors, an off-normal event has taken place. Alarm set points are established in SNF-6341, Spent Nuclear Fuel Cold Vacuum Drying Facility Alarm List. Alarm response procedures will be developed.

\subsubsection{System Shutdown}

The system shutdown process will be identified in the operational procedures.

\subsubsection{Safety Management Programs and Administrative Controls}

The safety management programs and administrative controls for this SDD will be integrated into the SNF Project Integrated Safety Management System.

\subsection{Testing And Maintenance}

The VPSCHW system is designed to operate through the design life of the equipment (five years) without regularly scheduled system shutdowns for maintenance. System maintenance activities are limited to maintenance due to failures. Additional maintenance activities and procedures may be scheduled if system surveillance, testing, or maintenance identifies additional 


\section{SNF-3087 REV 2}

requirements. All maintenance is performed under controlled procedures using approved equipment and materials. Only spare parts meeting design criteria are procured and used. The equipment has been designed for efficient maintainability. The surveillance, testing, and maintenance of the system are achieved at minimum cost and level of support services per DOE Order 6430.1A, Section 1300-12.4.10.

\subsubsection{Temporary Configurations}

There are no temporary configurations for the VPSCHW system.

\subsubsection{Technical Safety Requirement-Required Surveillances}

There are no technical safety requirement-related surveillances for the VPSCHW system.

\subsubsection{Non-Technical Safety Requirement Inspections and Testing}

Surveillance and in-service inspections of equipment are made per the manufacturer's recommendations. As dictated by the equipment operating manuals, surveillance is incorporated into the VPSCHW system standard operating procedures. Operators are expected to report all occurrences to their supervisors who in turn initiate an occurrence investigation. Accommodations have been made for both manual and electronic inspection of VPSCHW system equipment.

\subsubsection{Maintenance}

Maintenance features, including replacement of valves and piping connected to the primary barrier, are designed so that these activities are carried out under heating, ventilation, and air conditioning inflow or isolation. Equipment and components have been located away from potentially contaminated areas, whenever practical, to reduce contact with contamination and to minimize situations causing breach of containment. Modular design has been incorporated to facilitate change-out of systems requiring timely repair and/or special skills, and to reduce problems associated with equipment removal and repair. Commercial equipment, components, and parts are used wherever feasible to reduce procurement, maintenance, training, and inventory costs. Maintenance procedures will be developed.

\subsubsection{Equipment Calibration}

All equipment must be calibrated and recalibrated according to the respective manufacturer's recommended schedule and practice. Calibration and test connections are provided to enable inservice testing and calibration when practical. 
SNF-3087 REV 2

Appendix A

Source Documents

A-1 


\section{SNF-3087 REV 2}

\section{INDUSTRY STANDARDS AND CODES}

ANSI/ASME B16 Standards series, 1996, Fittings, Flanges and Valves, American Society of Mechanical Engineers, New York, New York.

ANSI/ASME B16.5, 1996, Pipe Flanges and Flanged Fittings, American Society of Mechanical Engineers, New York, New York.

ANSI/ASME B16.11, 1996, Forged Steel Fittings, Socket-Welding and Threaded, American Society of Mechanical Engineers, New York, New York.

ANSI/ASME B16.39, 1996, Malleable Iron Threaded Pipe Unions Classes 150, 250, and 300, American Society of Mechanical Engineers, New York, New York.

ANSI/ASME B18.2.1, 1992, Square and Hex Bolts and Screws Inch Series Including Hex Cap Screws and Lag Screws, American Society of Mechanical Engineers, New York, New York.

ANSI/ASME B31.3, 1996, Process Piping Code, American Society of Mechanical Engineers, New York, New York.

ANSI/ASME B31.5, 1995, Refrigerant Piping Code, American Society of Mechanical Engineers, New York, New York.

ANSI/ASME B31.9, 1996, General Services Piping Code, American Society of Mechanical Engineers, New York, New York.

ANSI/ARI 550, 1992, Centrifugal or Rotary Screw Water Chilling Packages, Air Conditioning and Refrigeration Institute, Arlington, Virginia.

ANSI/IEEE-577, 1993, Standard Requirements for Reliability Analysis in the Design and Operation of Safety Systems for Nuclear Power Generating Stations, Institute of Electrical and Electronics Engineering, Piscataway, New Jersey.

ANSI/NFPA 70, 1996, National Electrical Code, National Fire Protection Association, Quincy, Massachusetts.

ASME, 1995, Boiler and Pressure Vessel Code, American Society of Mechanical Engineers, New York, New York.

ASTM A36, 1993, Standard Specification for Structural Steel, American Society for Testing and Materials, West Conshohocken, Pennsylvania.

ASTM A105/A105M, 1996, Standard Specification for, Carbon Steel Forgings, for Piping Components, American Society for Testing and Materials, West Conshohocken, Pennsylvania. 


\section{SNF-3087 REV 2}

ASTM A197, 1987, Standard Specification for Cupola Malleable Iron, American Society for Testing and Materials, West Conshohocken, Pennsylvania.

ASTM A240, 1997, Standard Specification for Heat-Resisting Chromium and Chromium-Nickel Stainless Steel Plate, Sheet, and Strip for Pressure Vessels, American Society for Testing and Materials, West Conshohocken, Pennsylvania.

ASTM A269, 1996, Standard Specification for Seamless and Welded Austenitic Stainless Steel Tubing for General Service, American Society for Testing and Materials, West Conshohocken, Pennsylvania.

ASTM A276, 1997, Standard Specification for Stainless Steel Bars and Shapes, American Society for Testing and Materials, West Conshohocken, Pennsylvania.

ASTM A307, 1993, Standard Specification for Carbon Steel Bolts and Studs, 60,000 psi Tensile Strength, American Society for Testing and Materials, West Conshohocken, Pennsylvania.

ASTM A312/312M, 1995, Standard Specification for Seamless and Welded Austenitic Stainless Steel Pipes, Rev. A, American Society for Testing and Materials, West Conshohocken, Pennsylvania.

ASTM A354, 1997, Standard Specification for Quenched and Tempered Alloy Steel Bolts, Studs and other Externally Threaded Fasteners, American Society for Testing and Materials, West Conshohocken, Pennsylvania.

ASTM A479/A479M, 1997, Standard Specification for Stainless Steel Bars and Shapes for Use in Boilers and other Pressure Vessels, Rev. A, American Society for Testing and Materials, West Conshohocken, Pennsylvania.

ASTM A480/A480M, 1997, Standard Specification for General Requirements for Flat-Rolled Stainless Heat-Resisting Steel Plate, Sheet, and Strip, Rev. A, American Society for Testing and Materials, West Conshohocken, Pennsylvania.

ASTM A500, 1993, Grade B Specification for Cold Formed, Welded and Seamless Carbon Steel Structural Tubing in Rounds and Shapes, American Society for Testing and Materials, West Conshohocken, Pennsylvania.

ASTM A563, 1996, Standard Specification for Carbon and Alloy Steel Nuts, American Society for Testing and Materials, West Conshohocken, Pennsylvania.

ASTM F593, 1995, Standard Specification for Stainless Steel Bolts, Hex Cap Screws, and Studs, American Society for Testing and Materials, West Conshohocken, Pennsylvania.

ASTM F594, 1991, Standard Specification for Stainless Steel Nuts, American Society for Testing and Materials, West Conshohocken, Pennsylvania. 


\section{SNF-3087 REV 2}

SNT-TC-1A, 1996, Recommended Practice, American Society of Nondestructive Testing, Columbus, Ohio.

\section{GOVERNMENT DOCUMENTS}

10 CFR 830.120, "Quality Assurance," Code of Federal Regulations, as amended.

29 CFR 1910.120, "Occupational Safety and Health Standards," Code of Federal Regulations, as amended.

DOE Order 6430.1A, 1989, General Design Criteria, U.S. Department of Energy, Washington, D.C.

DOE-STD-1021, Natural Phenomena Hazards Design and Evaluation Criteria for Department of Energy Facilities, DOE Standard 1020-94, U.S. Department of Energy, Washington, D.C.

Ecology, 1994, Hanford Federal Facility Agreement and Consent Order, as amended, Washington State Department of Ecology, U.S. Environmental Protection Agency, and U.S. Department of Energy, Olympia, Washington.

\section{SPENT NUCLEAR FUEL PROJECT DOCUMENTS}

\section{Design}

HNF-SD-SNF-DRD-002, 2000, Cold Vacuum Drying Facility Design Requirements, Fluor Hanford, Inc., Richland, Washington.

HNF-SD-SNF-FRD-020, 1996, K Basin Spent Nuclear Fuel Cold Vacuum Drying Facility

Functions and Requirements, Westinghouse Hanford Company, Richland, Washington.

SNF-4248, 1999, Cold Vacuum Drying Facility Document Hierarchy Definition Document, DE\&S Hanford, Richland, Washington.

SNF-4396, 1999, Design Verification and Validation Plan for the Cold Vacuum Drying Facility, DE\&S Hanford, Richland, Washington.

SNF-4506, 1999, SNF CVD Facility Design Review Report, ARES Corporation, Richland, Washington.

\section{Safety}

HNF-3553, Annex B, 2000, Safety Analysis Report for the Cold Vacuum Drying Facility, Fluor Hanford, Inc., Richland, Washington. 


\section{SNF-3087 REV 2}

HNF-3673, 2000, Cold Vacuum Drying Facility Technical Safety Requirements, Fluor Hanford, Inc., Richland, Washington.

HNF-SD-SNF-CSER-006, 1999, Criticality Safety Evaluation Report for the Cold Vacuum Drying Facility's Process Water Handling System, Fluor Hanford, Inc., Richland, Washington.

HNF-SD-SNF-HIE-004, 1999, Cold Vacuum Drying Facility Hazard Analysis Report, Fluor Hanford, Incorporated, Richland, Washington.

HNF-SD-SNF-SEL-002, 2000, Spent Nuclear Fuel Project Cold Vacuum Drying Facility Safety Equipment List, Fluor Hanford, Inc., Richland, Washington.

SNF-2770, 2000, Cold Vacuum Drying Facility Design Basis Accident Analysis Documentation, Fluor Hanford, Incorporated, Richland, Washington.

SNF-AP-5-006, ALARA Goals, Training, and Control Level Administration, Fluor Hanford, Inc., Richland, Washington.

SNF-AP-5-012, Radiological ALARA Work Planning Process, Fluor Hanford, Inc., Richland, Washington.

SNF-AP-5-013, Radiological ALARA Process, Fluor Hanford, Inc., Richland, Washington.

\section{Specifications}

SNF-6209, 2000, Specification for W-441 Construction, Fluor Hanford, Inc., Richland, Washington.

W-441-C1, 2000, Construction Specification for Project W-441, Section 15400, Plumbing/Piping, Section 15510, Chilled Water Piping and Specialty Items, and Section 15681, Single Package Process Chiller

\section{Supporting Documents}

HNF-MP-599, 1997, Project Hanford Quality Assurance Program Description, Fluor Hanford, Inc., Richland, Washington.

SNF-3061, 2000, Cold Vacuum Drying Facility Civil/Structural/Architectural System Design Description, Fluor Hanford, Inc., Richland, Washington.

SNF-3062, 2000, Cold Vacuum Drying Facility Vacuum Purge System Design Description, Fluor Hanford, Inc., Richland, Washington.

SNF-3075, 2000, Cold Vacuum Drying Facility Electrical System Design Description, Fluor Hanford, Inc., Richland, Washington. 


\section{SNF-3087 REV 2}

SNF-3076, 2000, Cold Vacuum Drying Facility Specialty Equipment and Special Tools System Design Description, Fluor Daniel Hanford, Inc., Richland, Washington

SNF-3090, 2000, Cold Vacuum Drying Facility Monitoring and Control System Design Description, Fluor Hanford, Inc., Richland, Washington.

SNF-4148, 2000, Master Equipment List, Fluor Hanford, Inc., Richland, Washington.

\section{Vendor Information}

References to vendor information can be found in:

SNF-4148, 2000, CVDF Master Equipment List, Fluor Hanford, Inc., Richland, Washington.

References to vendor information include:

EM-9901-DUK-010, CVDF Equipment Manual for the PES Skid, Fluor Hanford, Inc., Richland, Washington.

\section{Operations}

SNF-2356, 2000, Spent Nuclear Fuel Project Cold Vacuum Drying Facility Operations Manual, Fluor Hanford, Inc., Richland, Washington.

\section{Off Normals}

SNF-5390, 2000, Spent Nuclear Fuel Project Cold Vacuum Drying Facility Off-Normal Event Analysis and Description, Fluor Hanford, Inc. Richland, Washington.

SNF-6341, 2000, Spent Nuclear Fuel Cold Vacuum Drying Facility Alarm List, Fluor Hanford, Inc., Richland, Washington.

\section{CALCULATIONS}

Calculations in support of the VPSCHW system design are located in:

SNF-3001, 2000, CVD Facility Supporting Data and Calculation Database, Fluor Hanford, Inc., Richland, Washington. 
SNF-3087 REV 2

Appendix B

System Drawings

B-1 
Complete sets of drawings are located with the Spent Nuclear Fuel Project files for the CVDF project.

Drawing Number

H-1-82162

H-1-82224

H-1-82228
Title

Cold Vacuum Drying Facility Process Equipment Skid

P\&ID Vacuum Pumping System

Cold Vacuum Drying Facility Mechanical Utilities Process Chilled Water P\&ID

Cold Vacuum Drying Facility Mechanical Utilities $2^{\text {nd }}$ Floor Process Chld Wtr
Sheet

Number

1

1

1 


\section{SNF-3087 REV 2}

Appendix C

System Procedures

C-1 


\section{SNF-3087 REV 2}

The VPSCHW system will be operated in accordance with the following procedures.

Operating Procedures

OP-47-004V

Special Procedures

SP-47-003V
Align, Start, Operate, and Secure VPSCHW

Surveillance of CHW/TWC/VPSCHW System

C-2 
SNF-3087 REV 2

Appendix D

System Procedures

D-1 


\section{SNF-3087 REV 2}

This section reserved for future system modifications or changes considered to be significant, such as changes to requirements, bases, TSR's, and setpoints. The maintenance and repairs considered to be of major significance will also be identified here. Each such modification or change, and maintenance or repair action should be briefly summarized and the appropriate documentation (e.g. design change packages, work packages) referenced. 


\section{DISTRIBUTION SHEET}

To

Distribution

Project Title $N$ Work Order

VPSCHW System Design Description

\section{Name}

K. McCracken

B. Ramsgate

B. Parker

J. Brehm

C. Haller

J. Irwin

P. Beaudet

D. Cole

C. Schweda

W. Alaconis

J. Gregory

SNF Startup Library

CVD Library (A. Artzer)

CVDF Satellite Library

T. Nuxall

SNF Project Files

C. Van Katwijk

G. Singh

C. Miska
From

SNF-CVD

\begin{tabular}{l} 
Page 1 of 1 \\
Date $5 / 30 / 00$ \\
\hline EDT No. \\
ECN No. 660509
\end{tabular}

\begin{tabular}{|c|c|c|c|c|}
\hline MSI & $\begin{array}{l}\text { Text } \\
\text { With All } \\
\text { Attach. }\end{array}$ & Text Only & $\begin{array}{c}\text { Attach./ } \\
\text { Appendix }\end{array}$ & $\begin{array}{l}\text { EDT/EC } \\
\text { Only }\end{array}$ \\
\hline
\end{tabular}

